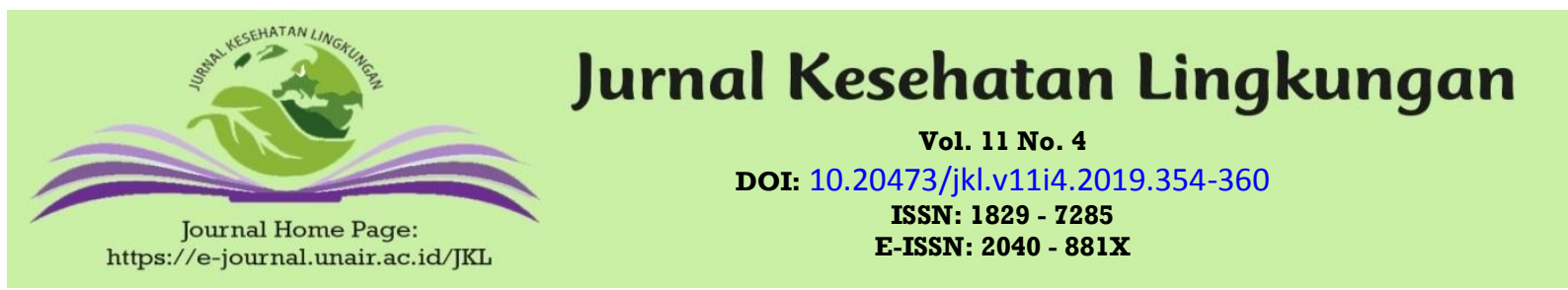

\title{
A Correlation Study : Levels of Butyrylcholinesterase and Paraoxonase 1 Activity amongst Shallot Farmworkers in Brebes Regency, Central Java, Indonesia
}

\author{
Suratman Suratman ${ }^{1}$, Kuswanto \\ Kuswanto $^{2}$ Agnes Fitria \\ Widiyanto $^{3}$ Department of Public Health, \\ Faculty of Health Sciences, Jenderal \\ Soedirman University, Purwokerto, \\ 53122
}

\section{Corresponding Author:}

suratman@unsoed.ac.id

\section{Article Info}

Submitted

: 01 July 2019

In reviewed

: 20 Agustus 2019

Accepted

: 22 Oktober 2019

Available Online:31 Oktober 2019

Kata kunci: Serum Kolinesterase, Paraoxonase 1, Petani Bawang Merah

Keywords: Butyrylcholinesterase, Paraoxonase 1, Shallot Farmworkers

Published by Fakultas Kesehatan Mayarakat Universitas Airlangga

\section{Abstrak}

Insektisida organofosfat adalah jenis pestisida yang biasa digunakan pada kegiatan pertanian untuk membasmi atau melindungi tanaman dari serangan hama jenis serangga. Selain manfaat yang ditawarkan, insektisida organofosfat juga membawa ancaman bagi individu dan populasi. Petani bawang merah di Kabupaten Brebes adalah salah satu populasi berisiko untuk terpapar oleh insekstida organofosfat. Tingkat aktivitas Butyrycholinesterase (BuChE) dan Paraoxonase 1 (PON1) dalam darah memiliki peran penting sebagai penanda biologis untuk mengukur terjadinya paparan dan mengukur tingkat kerentanan tubuh akibat paparan insektisida organofosfat. Penelitian ini bertujuan untuk menganalisis korelasi antara tingkat aktivitas BuChE dan PON1 pada petani bawang merah di Kabupaten Brebes. Penelitian ini merupakan penelitian observasional menggunakan cross sectional design. Sebanyak 88 orang petani di Desa Dukuhlo, Kecamatan Bulakamba, Kabupaten Brebes, Indonesia dipilih secara acak sebagai sampel penelitian pada periode bulan April dan Mei 2017. Instrument penelitian menggunakan kuesioner untuk mengetahui karakteristik sosial demografik dari subjek penelitian. Pengambilan sampel darah dilakukan untuk menentukan tingkat aktivitas BuChE dan PON1. Sampel darah kemudian dianalisis di laboratorium Cito Tegal dan Gaky Undip Semarang. Analisis data menggunakan univariat dan bivariat (uji korelasi Rank Spearman). Tingkat aktivitas BuChE berkorelasi positif dengan tingkat aktivitas PON1 dengan kekuatan hubungan sedang $(\mathrm{p}=0,025 ; \mathrm{rho}=0,238)$. Kesimpulan dari penelitian ini adalah terdapat korelasi positif antara kedua variabel tersebut. Petani dengan tingkat aktivitas PON 1 yang tinggi memungkinkan untuk mendetoksifikasi paparan akut insektisida organofosfat lebih baik. Penelitian lebih lanjut diperlukan untuk mengidentifikasi korelasi antara tingkat aktivitas PON1, kadar hormon tiroid, dan metabolit insektisida dalam urin.

\section{Abstract}

Organophosphate insecticides (OPs) are one of the pesticides commonly used in agricultural activities either to eradicate or to protect crops from insect attacks. Aside from the advantages proposed, this OPs substance also brings some worrisome threats for individual and population. Shallot farmworkers in Brebes Regency are population at risk to OPs exposure. The activity levels of Butyrylcholinesterase (BuChE) and paraoxonase 1 (PONI) in blood play important roles as a biomarker of exposure as well to measure the occurrence of OPs exposure in a human body and as a biomarker of susceptibility as well to measure the level of detoxifying OPs. The aim of this study was to analyse the correlation between levels of BuChE and PONI activities amongst shallot farmworkers. A cross-sectional study was conducted on 88 male subjects selected randomly from Dukuhlo Village in Brebes Regency, Indonesia, occupationally exposed to OPs from April to May 2017. Using a structured questionnaire, a survey was carried out based on sociodemographic characteristics. Blood samples were collected to determine the levels of BuChE and PON1 activity. These samples were then analysed at laboratories of Cito in Tegal and Gaky, Undip in Semarang. Furthermore, data were analysed systematically using univariate and bivariate (a Spearman's Rank test). A significant correlation was found between these both variables ( $p=0.025$ and rho $=0.238$ ) with slightly moderate positive relationship. To sum up, farmworkers with higher PON1 activity may have a better chance of detoxifying the acute effect of OPs exposure. A further research is needed to identify correlation between PON1 activity, levels of thyroid hormones, and OPs metabolites in urine. 


\section{INTRODUCTION}

In Indonesia, organophosphate insecticides (OPs) were chemical compounds extensively used for agricultural purposes. The active substance of OPs commonly used by farmworkers in Indonesia was chlorpyrifos (Suhartono, et al., 2012; Suratman, et al., 2015). Farmworkers were a population at risk to OPs exposure. The occurrences of acute poisonings among farmworkers occupationally exposed to OPs have been investigated by many researchers around the world (Suratman, et al., 2015). A study among 89 pesticide sprayers in Phnom Penh, Cambodia showed that most of the participants $(88 \%)$ suffered from symptoms of acute OPs poisoning (Jensen, et al., 2011). In addition, a study in 11 states of the USA during the period of $1998-2006$ among 2,945 cases related to agricultural pesticide drift demonstrated that $47 \%$ were occupationally exposed at work, $92 \%$ suffered from low severity illness, and the overall incidence was 114.3 farmworkers (in million person-years) (Lee, et al., 2011). A study in Turkey on 23 patients of acute OPs poisoning admitted to a hospital revealed that $65.2 \%$ of them were farmers (Soysal, et al., 2011). Similarly, a study on 77 fruit farmworkers in Tainan City, Taiwan demonstrated that a majority of them (92.2\%) had experienced one or more symptoms of acute poisoning due to OPs exposure (Weng \& Black, 2015). BuChE inhibition is used as a biomarker of exposure to OPs and is used to monitor farmworkers at risk of OPs exposure (BalaliMood \& Saber, 2012). Accumulation of the neurotransmitter Acetylcholine (ACh) occurs due to OPs that irreversibly block acetylcholinesterase (AChE) in the synapse and cause over-stimulation of nicotinic and muscarinic receptors (Colovic, et al., 2013; Lacasana, et al., 2010). Some epidemiological studies conducted in agricultural workers demonstrated that exposure to OPs decreased levels of butyryl cholinesterase (BuChE) (Dhananjayan, Ravichandran, Anitha, \& Rajmohan, 2012; Jamal, Haque, Singh, \& Rastogi, 2015; Neupane, Jørs, \& Brandt, 2017) and paraoxonase 1 (PON1) (Colovic, et al., 2013; Lacasana et al., 2010; Richard, et al., 2013) activities. PON1 activity was a key enzyme to detoxify OP pesticides and was used as a biomarker of susceptibility (Munoz-Quezad, et al., 2013).

Brebes Regency is an agricultural area located in Central Java Province, Indonesia that produces shallots as main commodities by which about $50 \%$ of farmworkers used chlorpyrifos (BPS-Statistics of Brebes Regency, 2016; Suratman, et al., 2015). The aim of this study was to assess the correlation between the levels of cholinesterase and PON1 activities among shallot farmworkers.

\section{METHOD}

This was a cross-sectional study to evaluate the levels of BuChE and PON1 activity based on the use of OPs among shallot farmworkers. Brebes Regency of Central Java Province is one of the most intensive agricultural areas in Indonesia with shallots as main agricultural commodities in the area. Dukuhlo Village located at Bulakamba Sub-District with the most intensive agriculture was selected as a research site. Inclusion criteria for participant selection were: 1) that they were male; and 2) had to be employed in farm work within the past 3 months. These criteria were based on the following: 1 ) the majority of farmworkers in 2013 in Indonesia (24.36 million or $77 \%$ ) (Indonesian Bureau of Statistics, 2013) were male; 2) engaging in farmwork within the past 3 months reflected recent likelihood of being exposed to OPs. In addition, complete recovery of BuChE as a biomarker of exposure to OP is 50 days (Mason, 2000). This study was conducted from April to May 2017, when pesticides were used less. As many as 88 eligible farmworkers had agreed to participate and signed informed consent forms. They were then interviewed and their blood samples were collected. Ethics approval was obtained from the Commission on Medical Research Ethics, Faculty of Medicine, Jenderal Soedirman University, Purwokerto, Indonesia with approval number: 1051/KEPK/III/2017.

ChE Gen 2 kit (PN 04498577190, Roche Diagnostics) on COBAS INTEGRA 800 was used for immediate BuChE determination. Enzymatic activity was obtained in $\mathrm{kU} / \mathrm{L}$ with normal values ranging from 5.32 to $12.92 \mathrm{kU} / \mathrm{L}$. Meanwhile, the ELISA method was performed on ELx800 (BioTek ${ }^{\circledR}$ Instruments, Inc) to determine PON1 activity according to the manufacturer's instructions. All these biomarkers were analysed by laboratory analysts working in two accredited laboratories, namely Cito Laboratory located in Tegal City for BuChE analysis, and Gaky Laboratory of Diponegoro University located in Semarang City for analyses of PON1 activity.

In addition, a structured questionnaire was used to collect data of personal characteristics, the use of OPs, methods of OP application, types of personal protective equipment worn during OPs application, and clinical signs and symptoms related to OPs exposure. The levels of BuChE activity had a normal data distribution $(p=0.243)$ whereas the data distribution of PON1 levels was not normal $(p=0.035)$ using a ShapiroWilk test. Therefore, a Spearman's Rank test 
was performed to analyse a correlation between these both variables.

\section{RESULTS AND DISCUSSION}

\section{Characteristics of the Study Population}

The characteristics of the research participants are presented in Table 1. More than $50 \%$ of the farmworkers have graduated from elementary school. Notwithstanding, the percentage of the research subjects who were never attended school were quite high (24\%). Meanwhile, the mean age of the farmworkers was 50.4 years old with the highest age was 70 years old. On an average, they had been working as a farmworker for 24.3 years and had length of work per day about 6 hours.

Table 1

Characteristics of the study population

\begin{tabular}{lrr}
\multicolumn{1}{c}{ Variables } & $\begin{array}{c}\text { Frequency } \\
\text { (F) }\end{array}$ & $\begin{array}{c}\text { Percent } \\
\text { (\%) }\end{array}$ \\
\hline $\begin{array}{l}\text { Level of education: } \\
\text { Never attended } \\
\text { school }\end{array}$ & 21 & 24 \\
Elementary School & 50 & 57 \\
$\begin{array}{l}\text { Junior High School } \\
\text { Senior High School }\end{array}$ & 11 & 12 \\
$\begin{array}{l}\text { Diploma } \\
\text { (D1/D2/D3) }\end{array}$ & 5 & 6 \\
$\begin{array}{l}\text { Age (year) } \\
\text { Years as a } \\
\text { farmworker } \\
\text { Length of work per } \\
\text { day (hour) }\end{array}$ & 1 & 1 \\
\hline
\end{tabular}

Age, years as a farmworker, and length of work per day are expressed as mean \pm standard deviation and minimum-maximum

\section{The Types of OPs used in the Last Four Weeks}

Table 2 presents the use of OPs by the research participants in the last four weeks to protect their crops. Almost half of the research subjects applied OPs to their crops in the last four weeks. The use of OPs was determined by identifying the active ingredients written on each label of pesticide container used by the participants.

Table 2

Use of OPs used in the last four weeks

\begin{tabular}{lrr} 
Use of pesticides & $\begin{array}{c}\text { Frequency } \\
\text { (F) }\end{array}$ & $\begin{array}{c}\text { Percent } \\
\text { (\%) }\end{array}$ \\
\hline Yes & 38 & 43 \\
No & 50 & 57 \\
\hline
\end{tabular}

\section{Last Time Applying Pesticides}

Table 3 presents the last time applying pesticides by the participants. Almost half of the subjects applied OPs in the last 1-6 days ago.

Table 3

Last time applying pesticides

\begin{tabular}{lcr}
\hline \multicolumn{1}{c}{$\begin{array}{c}\text { Last time applying } \\
\text { pesticides }\end{array}$} & F & $\%$ \\
\hline $1-6$ days ago & 41 & 47 \\
$1-2$ weeks ago & 27 & 31 \\
1 month ago & 17 & 19 \\
$>1$ month ago & 3 & 3 \\
\hline
\end{tabular}

\section{Methods of OPs Application}

Methods of OP application among the participants are presented in Table 4. All research participants frequently used sprayer backpack to apply OP to their crops and poured OP into the sprayer application tank by hand (100\%). In addition, nearly all subjects used equipment to stir the mixture when mixing OP such as dipper, tablespoon, and trowel (97\%). On the other hand, almost half of the participants were against wind direction when spraying OP (49\%).

Table 4

Methods of OP application

\begin{tabular}{lrr}
\hline Activities & $\begin{array}{c}\text { Frequency } \\
(\mathrm{F})\end{array}$ & $\begin{array}{c}\text { Percent } \\
(\%)\end{array}$ \\
\hline $\begin{array}{l}\text { Equipment used: } \\
\text { Backpack sprayer }\end{array}$ & 88 & 100 \\
$\begin{array}{l}\text { Ways to mix OPs: } \\
\quad \text { Pour into tank by hand }\end{array}$ & 88 & 100 \\
$\begin{array}{l}\text { Equipment used to mix OPs: } \\
\text { Hand/Arm }\end{array}$ & 1 & \\
$\quad$ Stick/Paddle & 1 & 2 \\
$\quad$ Other & 85 & 97 \\
Ways to spray OPs: & & \\
$\quad$ Wind direction & 45 & 51 \\
$\quad$ Against wind direction & 43 & 49 \\
\hline
\end{tabular}

Types of Personal Protective Equipment (PPE) frequently used

Types of PPE frequently used by farmworkers during working with OP are shown in Table 5.

Table 5

Types of PPE usually worn during working with OP

$\begin{array}{lcc}\text { Types of PPE worn } & \text { Frequency } & \text { Percent } \\ & \text { (F) } & \text { (\%) }\end{array}$

\begin{tabular}{lrr}
\hline Clothes: & 79 & 90 \\
$\quad$ Long sleeved shirt & 9 & 10 \\
$\quad$ Short sleeved shirt & & \\
Pants: & 47 & 53 \\
$\quad$ Long pants & 41 & 47 \\
$\quad$ Short & \\
\hline
\end{tabular}




\begin{tabular}{lrr}
\hline \multicolumn{1}{c}{ Types of PPE worn } & $\begin{array}{r}\text { Frequency } \\
(\mathrm{F})\end{array}$ & $\begin{array}{r}\text { Percent } \\
(\%)\end{array}$ \\
\hline Headwear: & 9 & 10 \\
$\quad$ Wide brim hat & 78 & 89 \\
$\quad$ Cap & 1 & 1 \\
$\quad$ No hat & & \\
Footwear: & 1 & 1 \\
$\quad$ Waterproof boots & 87 & 99 \\
$\quad$ No shoes & & \\
Mask: & 34 & 39 \\
$\quad$ Cloth mask & 54 & 61 \\
$\quad$ No mask & & \\
Gloves: & 2 & 2 \\
$\quad$ Waterproof elbow length & & \\
$\quad$ gloves & 1 & 1 \\
$\quad$ loth gloves & 85 & 97 \\
$\quad$ No gloves & & \\
$\quad$ Eye protections: & 88 & 100 \\
$\quad$ No eye protection & &
\end{tabular}

Most of the research participants were reported usually wearing long sleeved shirt $(90 \%)$, wearing long pants (53\%), wearing cap $(89 \%)$, not wearing footwear $(99 \%)$, not wearing mask $(61 \%)$, not wearing gloves $(97 \%)$, and not wearing eye protection (100\%) when working with OP.

\section{Levels of BuChE and PON1 activities}

Mean levels of BuChE and PON1 activities respectively were $7.7 \mathrm{kU} / \mathrm{L}$ and $8.9 \mathrm{ng} / \mathrm{ml}$ (Table $6)$.

Table 6

The levels of BuChE and PON1 activities

\begin{tabular}{lrrr}
\hline Biomarkers & mean \pm sd & Minimum & Maximum \\
\hline BuChE $(\mathrm{kU} / \mathrm{L})$ & $7.7 \pm 2.2$ & 1.6 & 13.4 \\
PON1 $(\mathrm{ng} / \mathrm{ml})$ & $8.9 \pm 2.5$ & 3.7 & 14.0 \\
\hline
\end{tabular}

BuChE activity was positively correlated with serum PON1 activity $(r=0.238, p=0.025)$ among farmworkers (Fig 1).

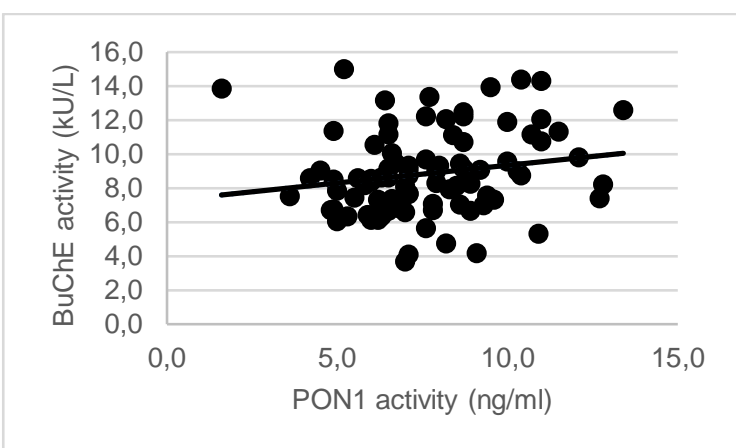

Fig 1

Correlation between BuChE and PON1 activities using a Spearman's Rank test ( $r$ ho $=0.238, p=$ 0.025)

\section{OP-related Symptoms}

A percentage of the participants complaining OP-related symptoms in the last four weeks is presented in Table 7. Some research participants reported OP-related symptoms like weakness $(3 \%)$, headache $(8 \%)$, dizziness $(19 \%)$, emesis $(6 \%)$, blurred vision $(15 \%)$, lacrimation (5\%), and muscle weakness (2\%).

Table 7

OP-related symptoms

\begin{tabular}{lrr}
\hline Symptoms & $\begin{array}{c}\text { Frequency } \\
\text { (F) }\end{array}$ & $\begin{array}{c}\text { Percent } \\
(\%)\end{array}$ \\
\hline Weakness: & 3 & 3 \\
Yes & 85 & 97 \\
No & 7 & 8 \\
Headache: & & \\
Yes & & \\
No & & \\
Dizziness: & 17 & 19 \\
Yes & 71 & 81 \\
No & & \\
Emesis: & 5 & 6 \\
Yes & 83 & 94 \\
No & & \\
Blurred vision: & 13 & 15 \\
Yes & 75 & 85 \\
No & & \\
Lacrimation: & 4 & 5 \\
Yes & 84 & 95 \\
No & & \\
Muscle weakness: & 2 & 98 \\
Yes & 86 & \\
No & & \\
\hline & &
\end{tabular}

\section{DISCUSSION}

Our study found 38 of 88 research participants (43\%) applied OPs compounds particularly chlorpyrifos to their crops (Table 2) and most participants $(47 \%)$ said that they used OPs for the last time within one to six days before being collected blood samples (Table 3 ). The length to recover from mild inhibition has been shown to be about 1-3 days whereas recovery from moderate inhibition is 1-2 weeks (Workplace Health and Safety Queensland, 2012).

A study conducted in South India among 28 agricultural workers occupationally exposed to OPs and 13 unexposed male workers as the reference group demonstrated that the levels of BuChE significantly declined about $56 \%$ among the exposed workers (Dhananjayan et al., 2012).

A study among male farmers in South Korea demonstrated that lifetime days of OPs application could increase risk of acute OPs poisoning $(\mathrm{OR}=1.74 ; 95 \% \mathrm{Cl}=1.32-2.29)(\mathrm{Kim}$ et al., 2013). PON1 has a capacity to hydrolyse the active metabolites of OPs including parathion, 
diazinon and chlorpyrifos specifically in the central nervous system (Costa, Giordano, Cole, Marsillach, \& Furlong, 2013). In addition, PON1 also play an important role in protecting a human body from some diseases related to oxidative stress like diabetes mellitus (Kulka, 2016).

In our study, the levels of BuChE statistically significantly correlated with the levels of PON1 activity. The finding of this study is consistent with the results of (Richard et al., 2013). They found that serum PON 1 positively correlated with cholinesterase activity among persons who consumed OPs and committed to suicide. In contrast, other studies showed that BuChE did not correlate with PON1 activity (Albers, Garabrant, Berent, \& Richardson, 2010; Ellison et al., 2012; Gonzalez et al., 2012).

The use of OPs in accordance with the pesticide labels is very important to be obeyed by farmworkers or pesticide applicators. Adverse health effects due to improper use of OPs often occur from acute to chronic conditions in around the world (Suratman, Edwards, et al., 2015). The inhibitions of both BuChE and red blood cholinesterase, known as AChE, by OPs compounds provide information of the OPs exposure in an individual (Marsillach et al., 2011). Furthermore, the levels of PON1 also need to be evaluated to determine individual susceptibility to OPs like chlorpyrifos (Albers et al., 2010).

BuChE and PON1 are two kinds of enzymes that can be found in the liver and plasma (Albers et al., 2010; Tvarijonaviciute et al., 2012). BuChE, also known as plasma cholinesterase (PChE) is included in the same structural class of protein like Acetylcholinesterase (Richard et al., 2013). OPs inhibit the activity of cholinesterase in hydrolysing $\mathrm{ACh}$, a neurotransmitter, into choline and acetate acid in order to prevent overstimulating post-synaptic nerves, muscles, and exocrine glands (King \& Aaron, 2015). BuChE is a sensitive biomarker to OPs exposure particularly chlorpyrifos (Hofmann et al., 2010). A biological half-life of chlorpyrifos is very short about 62 hours in fat tissue and 18 hours in plasma (Suratman, Edwards, et al., 2015).

In addition, clinical effects of OPs poisoning due to acetylcholine excess were suffered by some research participants, namely weakness, headache, dizziness, emesis, blurred vision, lacrimation, and muscle weakness (Table 7). It means that over-stimulation of muscarinic and nicotinic receptors had occurred. Clinical signs and symptoms commonly occurred on muscarinic receptors due to the inhibition of cholinesterase by OPs are sweating, lacrimation, constricted pupils, wheezing cramps, excessive salivation, vomiting, diarrhoea, tenesmus, blurred vision, bradycardia, and urinary incontinence (King \& Aaron, 2015). These signs and symptoms are also known as respiratory manifestations. On the other hand, clinical signs and symptoms due to ACh excess on nicotinic receptor encompass fasciculations, weakness, cramps, paralysis, twitching, respiratory embarrassment, cyanosis, tachycardia, and arrest (King \& Aaron, 2015). These signs and symptoms are recognised as muscular manifestations.

All farmworkers in the research site used backpack tank sprayer to apply OPs on their crops. Unfortunately, they poured OPs into tank using their hands (Table 4). In addition, most of them also did not wear proper PPE during working with OPs compounds (Table 5). This conditions potentially increased amount of OPs that entered their bodies through dermal absorption. Even though 57\% of the research participants did not use OPs in the last four weeks, the OPs exposure among them is still possible to occur. Unwitting exposure to OPs can happen when they visited their farming areas, touched crops that recently sprayed using OPs, inhaled air at the farming area, wore unwashed clothes after farming activities (Suratman, Edwards, et al., 2015). OPs could enter into the body through ingestion, inhalation, as well as absorption on the skin (Khan, Hashmi, Mahjabeen, \& Naqvi, 2010).

\section{CONCLUSION}

BuChE and PON1 activities in the serum of the shallot farmworkers were measured and positively and significantly correlated. Farmworkers with higher PON1 activity may have a better chance of detoxifying the acute effect of OPs exposure. Farmworkers in Brebes Regency need to change their methods in applying OPs and to wear PPE properly in order to prevent the increase of OPs exposure. Further research is needed to investigate the correlation between PON1 activity, the levels of thyroid stimulating hormones, and the levels of OPs metabolites in urine samples.

\section{ACKNOWLEDGEMENT}

We are grateful to all research subjects for their participation and facilitation. In addition, we thank Research Institution and Community Service (LPPM), Universitas Jenderal Soedirman, Purwokerto, Indonesia for providing funding to conduct this study. 


\section{REFERENCES}

Albers, J. W., Garabrant, D. H., Berent, S., \& Richardson, R. J. (2010). Paraoxonase status and plasma butyrylcholinesterase activity in chlorpyrifos manufacturing workers. J Expo Sci Environ Epidemiol, 20(1), 79-89.

https;//doi: 10.1038/jes.2009.9

Balali-Mood, Mahdi, \& Saber, Hamidreza. (2012). Recent advances in the treatment of organophosphorous posionings. Iran J Med Sci, 37 No. 2, June, 74-91.

BPS-Statistics of Brebes Regency. (2016). Brebes Regency in Figures 2016. Brebes, Indonesia.

Colovic, Mirjana B., Krstic, Danijela Z., LazarevicPasti, Tamara D., Bondzic, Aleksandra M., \& Vasic, Vesna M. (2013). Acetylcholinesterase Inhibitors: Pharmacology and Toxicology. Curr Neuropharmacol, 11, 315-335.

Costa, Lucio G., Giordano, Gennaro, Cole, Toby B., Marsillach, Judit, \& Furlong, Clement $E$. (2013). Paraoxonase 1 (PON1) as a genetic determinant of susceptibility to organophosphate toxicity. Toxicology, 307, May, 115-122.

https://doi: 10.1016/j.tox.2012.07.011

Dhananjayan, V., Ravichandran, B., Anitha, N., \& Rajmohan, H. R. (2012). Assessment of acetylcholinesterase and butyrylcholinesterase activities in blood plasma of agriculture workers. Indian $J$ Occup Environ Med, 16(3), December, 127130. doi: $10.4103 / 0019-5278.111755$

Ellison, C. A., Crane, A. L., Bonner, M. R., Knaak, J. B., Browne, R. W., Lein, P. J., \& Olson, J. R. (2012). PON1 status does not influence cholinesterase activity in Egyptian agricultural workers exposed to chlorpyrifos. Toxicol Appl Pharmacol. September,

https://doi: 10.1016/j.taap.2012.08.031

Gonzalez, V., Huen, K., Venkat, S., Pratt, K., Xiang, P., Harley, K. G., .. Holland, N. T. (2012). Cholinesterase and paraoxonase (PON1) enzyme activities in Mexican-American mothers and children from an agricultural community. J. Expo. Sci. Environ. Epidemiol., 22(6), 641-648. https://doi: 10.1038/jes.2012.61

Hofmann, J.N., Keifer, M.C., Checkoway, H., Roos, A.J. De, Farin, F.M., Fenske, R.A., . . . Furlong, C.E. (2010). Biomarkers of
Sensitivity and Exposure in Washington State Pesticide Handlers. Adv Exp Med Biol., 660, 19-27.

https://doi: 10.1007/978-1-60761-3503_3

Indonesian Bureau of Statistics. (2013). Laporan hasil sensus pertanian 2013 (The results of agricultural census in 2013). (5106005). Jakarta, Indonesia.

Jamal, F., Haque, Q. S., Singh, S., \& Rastogi, S. (2015). The influence of organophosphate and carbamate on sperm chromatin and reproductive hormones among pesticide sprayers. Toxicol Ind Health. https://doi: 10.1177/0748233714568175

Jensen, H. K., Konradsen, F., Jors, E., Petersen, J. H., \& Dalsgaard, A. (2011). Pesticide use and self-reported symptoms of acute pesticide poisoning among aquatic farmers in Phnom Penh, Cambodia. J Toxicol, 639814.

https://doi: 10.1155/2011/639814

Khan, D. A., Hashmi, I., Mahjabeen, W., \& Naqvi, T. A. (2010). Monitoring health implications of pesticide exposure in factory workers in Pakistan. Environ Monit Assess, 168(14), 231-240.

https://doi: 10.1007/s10661-009-1107-2

Kim, J. H., Kim, J., Cha, E. S., Ko, Y., Kim, D. H., \& Lee, W. J. (2013). Work-related risk factors by severity for acute pesticide poisoning among male farmers in South Korea. Int $J$ Environ Res Public Health, 10(3), March, 1100-1112. https://doi: 10.3390/ijerph10031100

King, A. M., \& Aaron, C. K. (2015). Organophosphate and carbamate poisoning. Emerg Med Clin North Am, 33(1), 133-151. https://doi: 10.1016/j.emc.2014.09.010

Kulka, M. (2016). A review of paraoxonase 1 properties and diagnostic applications. Pol $J$ Vet Sci, 19(1), 225-232. https://doi: 10.1515/pjvs-2016-0028

Lacasana, M., Lopez-Flores, I., Rodriguez-Barranco, M., Aguilar-Garduno, C., Blanco-Munoz, J., Perez-Mendez, O., . . Cebrian, M. E. (2010). Interaction between organophosphate pesticide exposure and PON1 activity on thyroid function. Toxicol Appl Pharmacol, 249(1), August, 16-24. https://doi: 10.1016/j.taap.2010.07.024

Lee, S. J., Mehler, L., Beckman, J., Diebolt-Brown, B., Prado, J., Lackovic, M., . . Calvert, G. M. (2011). Acute pesticide illnesses associated with off-target pesticide drift 
from agricultural applications: 11 States, 1998-2006. Environ Health Perspect, 119(8), June, 1162-1169. https://doi: 10.1289/ehp.1002843

Marsillach, J., Richter, R. J., Kim, J. H., Stevens, R. C., MacCoss, M. J., Tomazela, D., . . . Furlong, C. E. (2011). Biomarkers of organophosphorus (OP) exposures in humans. Neurotoxicology, 32(5), July, 656-660.

https://doi: 10.1016/j.neuro.2011.06.005

Mason, H. J. (2000). The recovery of plasma cholinesterase and erythrocyte acetylcholinesterase activity in workers after over-exposure to dichlorvos. Occup Med, 50(5), 343-347.

Munoz-Quezada, M. T., Lucero, B. A., Barr, D. B., Steenland, K., Levy, K., Ryan, P. B., ... Vega, C. (2013). Neurodevelopmental effects in children associated with exposure to organophosphate pesticides: a systematic review. Neurotoxicology, 39, October, 158-168.

https://doi: 10.1016/j.neuro.2013.09.003

Neupane, Dinesh, Jørs, Erik, \& Brandt, Lars. (2017). Plasma Cholinesterase Levels of Nepalese Farmers Following Exposure to Organophosphate Pesticides. Environ Health Insights, 11(0). https://doi: 10.1177/1178630217719269

Richard, S. A., Frank, E. A., \& D'Souza, C. J. (2013). Correlation between Cholinesterase and Paraoxonase 1 Activities:Case Series of Pesticide Poisoning Subjects. Bioimpacts, 3(3), August, 119-122. https://doi: 10.5681/bi.2013.024

Soysal, Dilek, Karakus, Volkan, Soysal, Ahmet, Tatar, Erhan, Yildiz, Bayram, \& Simsek, Hatice. (2011). Evaluation of Cases with Acute Organophosphate Pesticide Poisoning Presenting at a Tertiary Training Hospital Emergency Department: Intoxication or Suicide. Journal of Academic Emergency Medicine. doi: 10.5152/jaem.2011.036
Suhartono, Djokomoeljanto, RRJ. Sri, Hadisaputro, Suharyo, Subagio, Hertanto Wahyu, Kartini, Apoina, \& Suratman. (2012). Pesticide exposure as a risk factor for hypothyroidism in women at childbearing age in agricultural areas. $M$ Med Indones, 46(2), 91-99.

Suratman, Edwards, John William, \& Babina, Kateryna. (2015). Organophosphate pesticides exposure among farmworkers: pathways and risk of adverse health effects. Reviews on Environmental Health, 30(1), 65-79. https://doi: 10.1515/reveh-2014-0072

Suratman, Ross, Kirstin, Babina, Kateryna, \& Edwards, John William. (2015). Differences in practices of handling organophosphate pesticides (OPs) and OPrelated symptoms between Indonesian and South Australian Migrant Farmworkers: pre and post educational intervention. MIH, 19(4), 19-25.

Tvarijonaviciute, A., Kocaturk, M., Cansev, M., Tecles, F., Ceron, J. J., \& Yilmaz, Z. (2012). Serum butyrylcholinesterase and paraoxonase 1 in a canine model of endotoxemia: effects of choline administration. Res Vet Sci, 93(2), 668674.

https://doi: 10.1016/j.rvsc.2011.09.010

Weng, C. Y., \& Black, C. (2015). Taiwanese farm workers' pesticide knowledge, attitudes, behaviors and clothing practices. Int $J$ Environ Health Res, March, 1-12. https://doi:10.1080/09603123.2015.1020 415

Workplace Health and Safety Queensland. (2012). Organophosphate pesticide health monitoring guidelines. Queensland, Australia: Department of Justice and Attorney-General Retrieved from www.worksafe.qld.gov.au. 